\title{
Daughters in the Deuterocanonical Books of the Old Testament
}

\author{
MICHAt WOJCIECHOWSKI \\ Uniwersytet Warmińsko-Mazurski w Olsztynie \\ m.wojciechowski@uwm.edu.pl, ORCID: 0000-0002-5658-7512
}

\begin{abstract}
The instances where daughters are mentioned in the Greek books of the Old Testament are not numerous. They are interesting, however, and deserving of exegesis and interpretation. In Tobit and Ben Sira their relationship to fathers are stressed and this aspect is of importance, whether those relationships are good or strained. If the texts are compared with the Hebrew Bible, more light is thrown on the personalities of the daughters, and they are valued more highly. Some influence of the Greek civilization can be presupposed here. A link with the Mediterranean culture of honor and shame can also be traced, especially in Ben Sira.
\end{abstract}

Keywords: Daughter, Women in the ancient world, Father, Bible, Septuagint, Apocrypha, Deuterocanonical books, Tobit, Susanna, Ben Sira, Sirach, Anthropology, Family, Family values.

This article concerns mainly women and could be seen as inspired by feminist studies, although in this contemporary approach women are only rarely seen as daughters. Moreover, being a daughter implies a relationship in a family, with mother, father and their other children, and also a place in a society. Therefore, examining this matter is nearer to the social scientific and anthropological approach to the biblical studies. It has obviously ethical aspects, too. These interpretative tools will be useful for this study, but the basic step to be made before is a presentation of texts related to daughters in this part of the biblical literature. Jumping to conclusions is to be avoided, the review of the texts with comments concerning the situation of daughters in the given passages should precede more general sociological and ethical interpretations.

The texts in question are to be taken from the books and sections of the Septuagint which have no counterparts in the Hebrew Bible. Inside the article I shall label them Greek books of the Old Testament, avoiding a choice between their traditional theological names: "deuterocanonical books" in the Catholic canon and "Apocrypha" in the Protestant editions.

Mentions about daughters in the Hebrew Bible can be seen as a background for our research. However, they differ in character, probably because they correspond to an earlier period with a different (and worse) position of women. The subject 
of fathers and daughters in the Hebrew Bible has been adequately explored. ${ }^{1}$ There are further new studies related to this question; ${ }^{2}$ especially on Jephthah's daughter. ${ }^{3}$ However, I have found nothing concentrated on later, Greek Old Testament books. Some mentions are dispersed in the works concerning the position of women in the ancient Judaism. ${ }^{4}$

The position of daughters in the Hellenistic world would perhaps furnish a closer background for the views expressed in the later biblical books. Unfortunately, this matter has not been sufficiently researched. Information has to be looked for in general books on family ${ }^{5}$ and women ${ }^{6}$ in the Greek and Roman world.

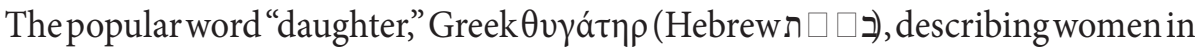
relation to their parents, occurs up to 66 times in this group of books (some manuscripts contain less). In some books it occurs more often (Tobit, Judith, Baruch, 1 Maccabees, 1 Esdras, Susanna = Daniel 13), in some there are only single cases (Wisdom of Solomon, 4 Maccabees), in others it cannot be found (2 and 3 Maccabees, other additions). We shall discuss these occurrences in a probable chronological order. ${ }^{7}$

1 Esdras, called also 3 Esdras, ${ }^{8}$ in its present form stems from an early Hellenistic period. As this book is a variation of traditions contained in Ezra and Nehemiah, its thought seems closer to the Persian period, before the $3^{\text {rd }}$ century B.C. Mentions of daughters are of lesser importance, what fits with the most of the Hebrew Bible.

Some are purely genealogical $(4: 29 ; 5: 38)$, referring to daughters of their fathers. Another text refers to daughters among other family members (5:1). However, in 5:38 we read: 9 "Of the priests the following had assumed the priesthood but were not found registered: [...] and the descendants of Jaddus who had married Agia, one of the daughters of Barzillai, and was called by his name." It seems that a son-in-law

1 Stiebert, Fathers and Daughters (with elements of anthropology).

2 Seifert, Tochter und Vater; Ben-Barak, Inheritance; McClenney-Sadler, Re-covering the Daughter's Nakedness; Fleishman, Father-Daughter; Westbrook, 'And He Will Take'.

3 Robinson, "The Story of Jephthah"; Berg, "Iphigenia in Israel"; Bauks, Jephtas Tochter.

4 Mayer, Die jüdische Frau; Archer, Her Price; Ilan, Jewish Women (cf. Ilan, Integrating Jewish Women); cf. Cohen, The Jewish Family in Antiquity.

5 E.g. Lacey, Family; Slater, The Glory of Hera; Pomeroy, Families; Harlow - Laurence, A Cultural History.

6 E.g. Kerenyi, Eleusis; Pomeroy, Goddesses; Pomeroy, Women; Holmberg Lübeck, Iphigeneia; Cameron Kuhrt, Images of Women; James - Dillon, A Companion to Women; Hallett, Fathers and Daughters. Cf. also Kraemer, "Jewish Mothers."

7 I have not considered mentions of daughters in non-canonical ancient Jewish literature, which remain outside the subject of this article. I shall only note that they do contain some mentions about daughters (listed together with the Apocrypha and the Mishnah by Collini, Famiglia, 86-87; on the incest Collini, Sessualità, 38-40). However, these mentions are brief and usually reflect the Old Testament laws concerning sexuality and children (Jubilees 20.4; 28.6-7; Qumran Temple Scroll 67.7-13; PseudoPhokilides, 198, 215-216; Philo, De vita Mosis 1.13; idem, De specialibus legibus 2.24; 4.178). Some texts discuss the inheritance of daughters (Testament of Job 46:2ff; Philo, De vita Mosis 2.234-236; idem, De specialibus legibus 2.124-125). Incest is mentioned surprisingly often.

8 Recent commentary: Böhler, 1 Esdras. In Polish: Wojciechowski, Apokryfy, 201-288.

9 Biblical quotations are from NRSV. 
through his marriage tried to gain privileges of a son, inheriting priestly descent. It would mean that a daughter was not simply given in marriage to pass to another family, but her lineage, resulting from relation to the father, was transmittable to her husband. However, this view is contested by the book.

Three further mentions, absent from some manuscripts and from the text established by the Göttingen critical edition, ${ }^{10}$ contain standard polemics against mixed marriages, forbidding giving daughters to pagan or taking their daughters (8:70.84 [twice]).

Tobit in its Greek form ${ }^{11}$ can be dated about the $3^{\text {rd }}$ century B.C., but it was probably based on an earlier Aramaic original. ${ }^{12}$ Its manuscript tradition is divided between two basic versions (the third one is mixed). The longer version, preserved in Sinaiticus, has to be considered earlier than the shorter one. It mentions the word "daughter" more often. This longer version contains lacunas, which should be filled from manuscript 319 and from the Old Latin, and not from the shorter version, as in many translations.

Despite of the fact that Tobit has roots in the oriental diaspora traditions, up to the Assyrian deportation, described in the book, as a story it is nearer to Hellenistic novels, with their interest in family, love and marriage, travels, adventures and happy ends. It contains both fairy tale elements and didactic theological conclusions. In this context we find important scenes presenting father and daughter, her plight and sadness, ${ }^{13}$ and finally her happy marriage. We will follow the respective texts. In Tobit 3 we read:

${ }^{7}$ On the same day, at Ecbatana in Media, it also happened that Sarah, the daughter of Raguel, was reproached by one of her father's maids. ${ }^{8}$ For she had been married to seven husbands, and the wicked demon Asmodeus had killed each of them before they had been with her as is customary for wives $[\ldots]{ }^{10}$ On that day she was grieved in spirit and wept. When she had gone up to her father's upper room, she intended to hang herself. But she thought it over and said, "Never shall they reproach my father, saying to him, 'You had only one beloved daughter but she hanged herself because of her distress.' And I shall bring my father in his old age down in sorrow to Hades. It is better for me not to hang myself, but to pray the Lord that I may die and not listen to these reproaches anymore." $[\ldots]{ }^{14}$ You know, O Master, that I am innocent of any defilement with a man, ${ }^{15}$ and that I have not disgraced my name or the name of my father in the land of my exile. I am my father's only child; he has no other child to be his heir; and he has no close relative or other kindred for whom I should keep myself as wife.

10 Hanhart, Esdrae liber I.

11 Critical edition: Hanhart, Tobit. Commentaries: Moore, Tobit; Fitzmyer, Tobit; Schüngel-Straumann, Tobit. In Polish: Wojciechowski, Księga Tobiasza.

12 More in Fitzmyer, Tobit, 18-28.

13 Egger-Wenzel, "Sarah's Grief." 
This text refers to the suicidal thoughts and depression (what is unique in the Bible, and seems to be of importance today). The remedy suggested by the author is that unhappy persons should think not about themselves, but about other people who care for them, about their family. Next, they should pray. Sarah asked God for death, what seems understandable and justified - but she would receive help.

Sarah manifests love for her father. She has good reasons to be unhappy, but turns her thoughts to him. She feels responsible for his future fate. She doesn't want him to be reproached after her suicide. Her death would have been a loss of his only child. Therefore, she decides to persist, in spite of circumstances: she makes an important choice concerning her life. Hence we can conclude that she is a responsible family member, far from being a pawn, a dependent female.

All this remains in a patriarchal context. The father has never been put to shame by his daughter and she wants to avoid it in future. The mother of Sarah, Edna, seems absent from her thoughts, although we learn nothing wrong about her. ${ }^{14}$ It can be surprising nowadays.

Sara sees the danger of pushing her father to sorrow and death, what is a universal moral motive. She also refuses a possibility that after her suicide, her father would have no heir and would be insulted. Here she considers social values of her time. Finally, in the framework of the culture of honour and shame, we find here an expression of authentic care and love of a daughter towards her father. Perhaps some direct experience of the author with the father-daughter relationship had furnished a background for this element of the plot.

The marriage of Sarah with Tobias comes next. In Tobit 6 we meet Sarah as daughter once more:

6:11 Raphael said to the young man [...] "We must stay this night in the home of Raguel. He is your relative, and he has a daughter named Sarah. ${ }^{12} \mathrm{He}$ has no male heir and no daughter except Sarah only, and you, as next of kin to her, have before all other men a hereditary claim on her. $[\ldots]{ }^{13}[\ldots]$ Raguel can by no means keep her from you or promise her to another man without incurring the penalty of death according to the decree of the book of Moses. Indeed he knows that you, rather than any other man, are entitled to marry his daughter. [...]"

Raphael gives instructions to Tobias concerning his future bride here. She is presented according to her position in the family as daughter and the only heir of Raguel (6:12). However, her father cannot decide about her marriage, because according to the rules of endogamy only Tobias, her first cousin, ${ }^{15}$ is entitled to marry her.

14 Cf. Lev 19:3 with mother on the first place.

15 We say "cousin," but words "brother" and "sister" are consistently used in the book. In NRSV I quote we find "kinswoman," but I change it into "sister" in the texts, preferring a more literal rendering. These names can also refer to them as husband and wife. 
The said rule stems from the "book of Moses" (6:13), probably because of the endogamy of patriarchs. ${ }^{16}$ It suggests that the previous attempts of marrying Sarah to other men were unlawful and father should not take such decisions. It seems that the power of the father over his daughter is in this case limited by law, and he is not, as often in the Ancient Near East and the Bible, an owner of his progeny.

The next chapter (Tobit 7) describes the visit to Raguel and marital negotiations. Raguel admits that Tobias has right to marry her daughter Sarah, but warns him of the danger. Tobias insists and Raguel makes the marriage contract. He avoids saying he is giving her daughter in marriage, but declares: "She is given to you in accordance with the decree in the book of Moses, and it has been decreed from heaven that she be given to you." It means that Law and divine will supersede the father's rights.

Raguel pronounces the formula of marriage: "Take your sister; from now on you are her brother and she is your sister. She is given to you from today and forever." The marriage is supposed to be durable (cf. 8:7). Next Raguel blesses the married couple and gives a written confirmation "that he gave her to him as wife according to the decree of the law of Moses." Once more, father is to fulfill the law, and not to make free decisions concerning his family.

In the next paragraph Sarah appears finally as the daughter of her mother. Edna says in a personal way: "Take courage, my daughter; the Lord of heaven grant you joy in place of your sorrow. Take courage, my daughter" (7:16). Mother is to console and reinforce her daughter in a difficult moment.

Later Sarah is to leave with Tobias. It involves new mentions of her as a daughter. During the wedding feast Raguel says to Tobias: "You shall cheer up my daughter, who has been depressed" (8:20). He remains a caring father. He would like to keep Sarah and Tobias longer, but Tobias wants to see his parents. The warm and moving farewell contains kisses, blessings and maternal request, accompanied with the following instruction:

\begin{abstract}
10:12 Then he kissed his daughter Sarah and said to her, "My daughter, honor your fatherin-law and your mother-in-law, since from now on they are as much your parents as those who gave you birth. Go in peace, daughter, and may I hear a good report about you as long as I live." Then he bade them farewell and let them go. Then Edna said to Tobias, "My child and dear brother, the Lord of heaven bring you back safely, and may I live long enough to see children of you and of my daughter Sarah before I die. In the sight of the Lord I entrust my daughter to you; do nothing to grieve her all the days of your life. Go in peace, my child. [...]".
\end{abstract}

It is striking that parents-in-law become proper parents. It has been already said of Tobias with Raguel and Edna as his parents (8:21). Marriage concerns the whole

16 Cf. on Biblical endogamy: Hieke, "Endogamy"; Miller, Marriage. 
family and creates new, strong parent-child relations. Accordingly, Sarah, presented once more in 11:15 as the daughter of Raguel, is warmly welcomed by old Tobit as his daughter:

${ }^{11: 17}$ Come in, my daughter, and welcome. Blessed be your God who has brought you to us, my daughter. Blessed be your father and your mother, blessed be my son Tobias, and blessed be you, my daughter. Come in now to your home, and welcome, with blessing and joy. Come in, my daughter".

The remaining text, Tobit 4:13, refers not to Sarah, but to the "sons and daughters of your people." ${ }^{17}$ Here we have a concept of Israel as a community of both men and women seen as a one family (cf. in Baruch below). Perhaps there is relation between this view and endogamy.

Baruch in Greek can be dated with some probability on the $3^{\text {rd }}$ century B.C., with a Hebrew original for prayers from Bar 1:15-3:8. Some scholars seek a Hebrew or Aramaic original for the rest of the book, but it is far from certain. ${ }^{18}$

Accordingly, Bar 2:3 remains in line with the Hebrew Bible, when it mentions horrors from Jerusalem under siege (cf. Lamentations): "Some of us ate the flesh of their sons and others the flesh of their daughters." Sons and daughter are parallel as children.

The remaining mentions refer to the sons and daughters of Jerusalem in exile. Jerusalem personifies the chosen people. Tobit 4:13 confirms a similar use.
${ }^{4: 10}$ for I have seen the exile of my sons and daughters, which the Everlasting brought upon them. [...]
${ }^{14}$ Let the neighbors of Zion come; remember the capture of my sons and daughters, which the Everlasting brought upon them.[...]
${ }^{16}$ They led away the widow's beloved sons, and bereaved the lonely woman of her daughters.

Israel is considered a community of men and women, both remaining in filial relation with her mother, Jerusalem, the holy city, both belonging to her, both nurtured and loved by her. Children of both sexes are seen here at equals. ${ }^{19}$

17 So shorter text (cf. a filiis et filiabus in OL, W; cum filiabus... filiarum; Speculum, 371, 460); "daughters of the sons" in manuscript 319; lacuna in Sinaiticus; cf. Hanhart, Tobit, 92.

18 Commentaries with ample discussions of introductory matters: Moore, Daniel, 255-358; Assan-Dhôte Moatti-Fine, Baruch; Adams, Baruch. In Polish: Wojciechowski, Ksiega Barucha. For our passages also Xeravits, "Take courage".

19 Cf. also Psalms of Solomon 8:21 on Pompey: "He led away their sons and daughters." 
Susanna, as a Greek addition to Daniel (Daniel 13) could be dated about 100 B.C. ${ }^{20}$ However, this short story refers to the Eastern diaspora situation, as Tobit and Baruch. The oriental stylization and the plot also seem to stem from an earlier period. In the Septuagint version Susanna is described seven times as daughter.

Three times she is identified simply as "daughter of Hilkiah" (Dan 13:2.7.29); children are named after their father. Once she is a "daughter of Israel" (13:48), unjustly accused. In Dan 13:57 there is a question of "daughters of Israel" who ceded to the blackmail of the two wicked elders. Courageous Susanna, however, appears here as a "daughter of Judah." Being such a daughter means belonging to the people of God, composed both of men and women.

Dan 13:3 presents the background of Susanna: "Her parents were righteous, and had trained their daughter according to the law of Moses." Here she is a daughter of both parents and she has received from them a good example as well as a religious education. It has made her a moral and conscious person. It suggests that girls should receive such an education.

Dan 13:63 (Theodotion) adds: "Hilkiah and his wife praised God for their daughter Susanna, and so did her husband Joakim and all her relatives, because she was found innocent of a shameful deed." Here we meet the principle that any behaviour of one family member brings honour or shame to the relatives. This daughter made nothing shameful (ä $\sigma \chi \eta \mu \mathrm{o} \pi \rho \tilde{a} \gamma \mu \alpha$ ) and should be praised. We should note, however, that Susanna had chosen a behaviour which was morally correct and honourable, even if it could lead to death and a dishonour in the eyes of the people and her family.

Ben Sira (Sirach, Ecclesiasticus) in its Greek form is dated after 132 B.C. and its Hebrew original was probably written between 195 and 180 B.C. ${ }^{21}$ Its advice concerning moral and religious conduct does include some mentions about daughters. For textual reasons they are difficult to count, because this book exists in two Hebrew and two Greek forms, with variants from Old Latin and Syriac. Nevertheless the message is quite clear. It concerns fathers and daughters. ${ }^{22}$

Presenting the texts I shall start from the vices attributed to young women in Ben Sira and further I shall proceed to the recommended father's reactions. The author has not ordered his views in such a way, his remarks on daughters remain dispersed.

${ }^{22: 3}$ It is a disgrace to be the father of an undisciplined son,

and the birth of a daughter is a loss.

20 Commented either with the book of Daniel (e.g. Parchem, Ksiega Daniela, 697-729) or separated (Moore, Daniel, 77-116). Susanna has raised the interest of readers because of her chastity and as a female character, but not as a daughter.

21 Greek text in Ziegler, Sapientia. Hebrew text in Beentjes, The Book of Ben Sira. Leading commentaries: Skehan - Di Lella, The Wisdom; Marböck, Jesus Sirach; Corley, Sirach.

22 Kułaczkowski, "Specyfika"; Pikuła, "Nad córką zuchwałą." These articles describe the opinions of Ben Sira correctly, but without a critical distance. 
${ }^{4}$ A sensible daughter obtains a husband of her own, but one who acts shamefully is a grief to her father.

${ }^{5}$ An impudent daughter disgraces father and husband, and is despised by both.

${ }^{26: 10}$ Keep strict watch over a headstrong daughter, ${ }^{23}$ or else, when she finds liberty, she will make use of it.

${ }^{11}$ Be on guard against her impudent eye, and do not be surprised if she sins against you.

${ }^{12}$ As a thirsty traveler opens his mouth and drinks from any water near him, so she will sit in front of every tent peg and open her quiver to the arrow.

${ }^{42: 11 a}$ Keep strict watch over a headstrong daughter, ${ }^{24}$ or she may make you a laughingstock to your enemies, a byword in the city and the assembly of the people, and put you to shame in public gatherings.

According to the author, daughters can bring shame on fathers through their impudent behaviour and sexual misconduct. Perhaps it meant that fathers failed to keep them under control. The author wants to fight the sinful attitudes, but because of his patriarchal ideals and values he seems not to understand the changing world around. Perhaps the situation he deplores reflects the influence of the Hellenistic civilization, where women became much more liberated and independent than before. ${ }^{25}$ We have here a textbook example of the patriarchal ideas of honour and shame in conflict with the ongoing social change.

Further the author seeks for a remedy, namely a stricter control over social contacts (Sir 42:11b-13). Finally (v. 14): "It is woman who brings shame and disgrace"; an allusion to daughters was perhaps clearer in the underlying Hebrew text. ${ }^{26}$ It meant

23 So in Greek, but perhaps in Hebrew and in Syriac a wife is meant (Skehan - Di Lella, Wisdom, 344, 346); the Greek editor was apparently more absorbed with daughters than with wives. Lower, in v. 12, we find euphemisms for having sex.

"Headstrong" not in Hebrew text; added apparently after Sirach 26:10. In Greek ả $\delta$ iá $\tau \rho \varepsilon \pi \tau o c$, that cannot

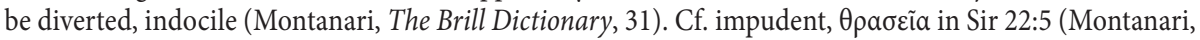
The Brill Dictionary, 948: also bold, audacious). These two words have often a positive meaning in Greek. Other negative adjectives are ảvaı $\delta \dot{\eta} \varsigma$, impudent, cheeky, shameless (Sir 26:11; Montanari, The Brill

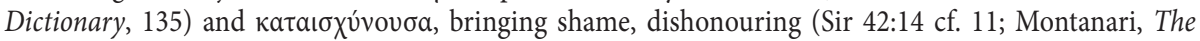

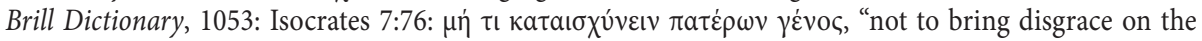
stock of your fathers").

25 However, even earlier there were similar complaints about daughters: Euripides, Andromache, 943, Aristophanes, Thesmophoriazousai, 414-415; 790-791.

26 Other possibilities: "but better a religious daughter than a shameless son" (Skehan), or: "but better a daughter of a religious wife than a son of the shameless one" (Cross); quoted after Skehan - Di Lella, 
a move back to the traditional patriarchal power over the family and keeping daughters away of the external world, where she can meet men and women with sexual experiences. The author does not realize that an excessive control provokes the results he deplores: resistance and lack of responsibility.

On the other hand, he sees the guard over daughters as a positive moral duty of fathers. They are also responsible for finding them good husbands. Girls should remain under the patriarchal power, but it is considered necessary for their own good. Fathers should care for their well-being and future happiness:

${ }^{7: 24}$ Do you have daughters? Be concerned for their chastity, and do not show yourself too indulgent with them.

${ }^{25}$ Give a daughter in marriage, and you complete a great task;

but give her to a sensible man.

This line of thought is further completed by a peculiar opinion that women can be given in marriage to any man (even if an intelligent one should be preferred), whereas men are choosy and have their own preferences. Sirach 36:26 [23 LXX] says: "A woman will accept any man as a husband, but one girl is preferable to another"

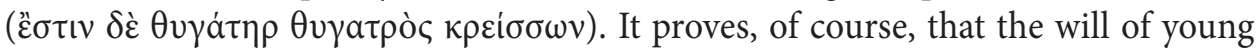
women was not taken into account. "Daughter" is a synonym of "girl" here.

Despite his antifeminism, the author realizes difficulties women can encounter in their life. Therefore, fathers are most anxious about the fate of their daughters. They care for them and are frustrated by the number of dangers to avoid, feeling responsible for the successful life of their children and personally endangered by their failures and misfortunes. A daughter can become a spinster, or can be repudiated if married, she can be seduced and pregnant outside a wedlock, and in marriage either unfaithful or barren. No way out... This list seems both satiric and realistic:

\footnotetext{
${ }^{42: 9}$ A daughter is a secret anxiety to her father, and worry over her robs him of sleep; when she is young, for fear she may not marry, or if married, for fear she may be disliked; ${ }^{10}$ while a virgin, for fear she may be seduced and become pregnant in her father's house; or having a husband, for fear she may go astray, or, though married, for fear she may be barren.
}

The remaining mentions of daughters in the Greek books of the Old Testament are mostly generic and usually do not deserve much attention. 1 Maccabees

Wisdom, 478 and 480. 
refers several times to daughters. However, in 5:8 and 5:65 "daughters" are villages neighbouring a town. Six mentions concern dynastic marriages of Hellenistic kings (10:54.57.58; 11:9.10.12). In 9:37 "daughter" is an Arab princess whose wedding was attacked by the Jewish guerillas. It reflects a minimal interest for women in this book.

In Judith, on the contrary, a woman plays the central role in the plot, and this fact was raised hundreds if not thousands times by scholars and writers - but only some passing remarks concern daughters. In 8:1 and 16:6 Judith is identified as "the daughter of Merari." In 9:4 there is a question of foreign women in captivity. In 10:12 Judith is a fleeing "daughter of the Hebrews" to become "like a daughter of the sons of Assur" in 12:13. "Daughter" means only an origin from a father or from a people, seen matter-of-factly. On the other hand, Uzziah says later to Judith:

13:18 O daughter, you are blessed by the Most High God above and other women on earth; and blessed be the Lord God, who created the heavens and the earth, who has guided you to cut off the head of the leader of our enemies.

It is exceptional. His declaration expresses both affection, care and recognition. Judith is a living treasure, precious and beloved for the people and for the leader of her city. As the leader represents the city, it seems that being their daughter equals to an adoption or an honorary citizenship. Such a daughter is someone special for God as well, although she is not called his daughter. We are not far from "blessed are you among women" (Luke 1:42).

In the late Jewish Hellenistic Wisdom of Solomon there is only one mention of daughters. Solomon says to God: "You have chosen me to be king of your people and to be judge over your sons and daughters" (Wisdom 9:7). Men and women were already named sons and daughters of Israel or of Jerusalem in the Greek books of the Old Testament, now they both appear to be children of God. It implies their religious equality. However, this way of speaking is not original, being known from the Hebrew Bible (Deut 32:19; Isa 43:6), even if "sons" are much more frequent there.

4 Maccabees contains a praise of the mother of seven martyrs: "She did not approve the deliverance that would preserve the seven sons for a short time, but as the daughter of God-fearing Abraham she remembered his fortitude" (4 Macc 15:27-28). Being a daughter means here to be a honourable descendant of Abraham and member of the people of Israel. 


\section{Conclusions}

These mentions about daughters in the later, Greek books of the Old Testament reveal a complex and multi-faceted usage of the word and variety of situations the daughters appear in. However, there are some implied anthropological and moral ideas behind the texts we have read. My conclusions can be presented in two groups. First group (1-6) is more closely related to the ancient standard social values. ${ }^{27}$ In the second group (7-10) new approaches appear, inspired either by a social change or by an internal evolution of the Jewish religion and moral considerations.

1. In some texts there is just a question of indicating who is the father of a woman, according to the current ancient usage (1 Esdras 4:29; 5:38; Tob 3:7,17; 6:11; Dan 13:2.7.29; 1 Macc 9:37; Jdt 8:1; 16:6). Occasionally, a national origin is meant (Dan 13:48.57; Jdt 10:12; 12:13).

2. Daughter is a person remaining under the power and responsibility of the father. She should be subordinated. However, we learn that girls not necessarily fit into this frame (Sir 22:3.5; 26:10-12; 42:11-14). The patriarchal ideology was sometimes in conflict with the reality and with the ambitions of young women.

3. Daughters can bring honour to their fathers and to the whole family (Tob; Dan 13:3,63).

4. Daughters can also become a source of trouble (Sir 42:9-10) and public shame (Sir 22:3-5; 26:11-12; 42:11.14), what makes fathers horrified and push them to interventions (Sir 26:10; 42:11-14; 7:24). Daughters may prefer to avoid such situations, showing understanding to the feelings of their fathers (Tob 3:10.15).

5. Daughters are given in marriage by their fathers (Tob 7:11-13; Sir 7:25) and sometimes they can transmit to the husband the inheritance of their family (Tob 6:12; 10:10; cf. 1 Esdras 5:38). However, they deserve good husbands (Tob; Sir 22:4; 7:25). They should not be given to pagans (1 Esdras 8:70.84 mss); sometimes an endogamy is recommended (Tob 6:13; 7:11-12). Father's power is limited in this respect.

6. Daughters belong to family (1 Esdras 5:1; Tob 3:15); they are related to both parents (Dan 13:3.63), although the role of mothers is rarely stressed (Tob 7:16).

7. Some women identified as daughters appear as independent persons with their own will (Sir 22:3.5; 26:10-12; 42:11-14) - and it is often approved (Tob 3:10; Dan 13; Judith).

8. "Sons and daughters" can denote the membership of both men and women in the religious and national community of Israel (Tob 4:13; Bar 4:14,16; Wis 9:7; cf. Dan 13:3; 4 Macc 15:28). It presupposes an idea of equality between them, even if vague.

27 Cf. e.g. Pilch - Malina, Handbook of Biblical Social Values. 


\section{MICHAt WOJCIECHOWSKI}

9. Daughters should be cared for and assisted in their plight; fathers should reckon with the difficulties and dangers the daughters encounter (Tob; Sir 42:9-10). It presupposes their rights and value in the family context.

10. Daughters are to be loved and important for their parents (Tob 8:20) and they love them, they care for they good (Tob 3:10). It applies to in-laws (Tob 10:12; 11:17). Personal relations in the family are taken for granted, even if they are not always satisfying. Life is family centered, especially in Tobit, what makes daughters important for the family relations.

Some of these observations fit well in the social background of the ancient world. We meet patriarchal mentality, daughters dependent of their fathers, culture of honour and shame. On the other hand there are some original features, at odds with the most of the Hebrew Bible. Daughters should be cared for and fathers feel responsible for their destiny. They answer with love, but also manifest some independence in decisions, even if their behaviour is sometimes considered wrong and shameful. Both men and women belong to the religious and national community. In brief: in the world presented in the Greek books of the Old Testament daughters not always stayed in the patriarchal shadow. They became important.

\section{Bibliography}

Adams, S.A., Baruch and the Epistle of Jeremiah. A Commentary Based on the texts in Codex Vaticanus (Leiden - Boston, MA: Brill 2014).

Archer, L.J., Her Price is Beyond Rubies. The Jewish Woman in Greco-Roman Palestine (Journal for the Study of the Old Testament. Supplements Series 60; Sheffield: Sheffield Academic Press 1990).

Assan-Dhôte, I. - Moatti-Fine, J., Baruch, Lamentations, Lettre de Jérémie (La Bible d’Alexandrie 25.2; Paris: Cerf 2005).

Bauks, M., Jephtas Tochter: Traditions-, Religions- und Rezeptionsgeschichtliche Studien $z u$ Richter 11, 29-40 (Forschungen zum Alten Testament 71; Tübingen: Mohr Siebeck 2010).

Beentjes, P.C., The Book of Ben Sira in Hebrew (Supplements to Vetus Testamentum 68; Leiden: Brill 1997).

Ben-Barak, Z., Inheritance by Daughters in Israel and the Ancient Near East; A Social, Legal and Ideological Revolution (Jaffa: Archaeological Center Publications 2006).

Berg, N.E., "Iphigenia in Israel: the Daughter's Options in Hebrew Literature," Hebrew Studies 50 (2009) 195-213.

Böhler, D., 1 Esdras (Internationaler Exegetischer Kommentar zum Alten Testament; Stuttgart: Kohlhammer 2015).

Cameron, A. - Kuhrt, A. (ed.) Images of Women in Antiquity, 2nd edition (London: Routledge 1993).

Cohen, S.J.D. (ed.), The Jewish Family in Antiquity (Brown Judaic Studies 289; Atlanta: Scholars 1993). 
Collini, P., Famiglia (Indice Concettuale del Medio Giudaismo 1; Magnano: Qiqajon 2000).

Collini, P., Sessualità (Indice Concettuale del Medio Giudaismo 2; Magnano: Qiqajon 2000).

Corley, J., Sirach (New Collegeville Biblical Commentary. Old Testament 21; Collegeville, MN: Liturgical Press 2013).

Egger-Wenzel, R., "Sarah's Grief to Death (Tob 3:7-17)," Ancient Jewish Prayers and Emotions. Emotions Associated with Jewish Prayer in and around the Second Temple Period (ed. S.C. Reif - R. Egger-Wenzel) (Deuterocanonical and Cognate Literature Studies 26; Berlin - Boston, MA: de Gruyter 2015) 193-219.

Fitzmyer, J.A., Tobit (Commentaries on Early Jewish Literature; Berlin - New York: de Gruyter 2003).

Fleishman, J., Father-Daughter Relations in Biblical Law (Bethesda, MD: CDL 2011).

Hallett, J.P., Fathers and Daughters in Roman Society (Princeton: Princeton University Press 1984).

Pilch, J.J. - Malina, B.J. (ed.), Handbook of Biblical Social Values (Peabody, MA: Hendrickson 1998).

Hanhart, R. (ed.), Esdrae liber I, 2nd edition (Septuaginta Vetus Testamentum Graecum 8/1; Göttingen: Vandenhoeck \& Ruprecht 1991).

Hanhart, R. (ed.), Tobit (Septuaginta Vetus Testamentum Graecum 8/5; Göttingen: Vandenhoeck \& Ruprecht 1983).

Harlow, M., - Laurence, R., A Cultural History of Childhood and Family in Antiquity (London: Bloomsbury 2010).

Hieke, T., "Endogamy in the Book of Tobit, Genesis, and Ezra-Nehemiah," The Book of Tobit: Text, Tradition, Theology (ed. G. Ceravits - J. Zsengllér) (Journal for the Study of Judaism Supplement Series 98; Leiden: Brill 2005) 103-120.

Holmberg Lübeck, M., Iphigeneia, Agamemnon's Daughter: Study of Ancient Conceptions in Greek Myth and Literature Associated with the Atrides (Stockholm: Almquist \& Wiksell 1993).

Ilan, T., Integrating Jewish Women into Second Temple History (Tübingen: Mohr Siebeck 1999).

Ilan, T., Jewish Women in Greco-Roman Palestine. An Inquiry into Image and Status (Texte und Studien zum antiken Judentum 44; Tübingen: Mohr Siebeck 1995).

James, S.L. - Dillon, S. (ed.), A Companion to Women in the Ancient World (Chichester: Blackwell 2015).

Kee, H.C. (ed.), New Revised Standard Version. Cambridge Annotated Study Apocrypha (NRSV) (Cambridge: CUP 1994).

Kerenyi, C., Eleusis: Archetypal Image of Mother and Daughter (London: Routledge - Paul 1967).

Kraemer, R.S., "Jewish Mothers and Daughters in the Greco-Roman World," The Jewish Family in Antiquity (ed. S.J.D. Cohen) (Brown Judaic Studies 289; Atlanta, GA: Scholars 1993) 89-112.

Kułaczkowski, J., "Specyfika wychowawczej funkcji ojca wobec córki w ujęciu Księgi Syracha," Seminare 20 (2004) 31-48.

Lacey, W.K., Family in Classical Greece (London: Thames \& Hudson 1968).

Marböck J., Jesus Sirach 1-23 (Herders theologischer Kommentar. Altes Testament; Freiburg Basel - Wien: Herder 2010).

Mayer, G., Die jüdische Frau in der hellenistisch-römisch Antike (Stuttgart: Kohlhammer 1987). 


\section{MICHAt WOJCIECHOWSKI}

McClenney-Sadler, M.G., Re-covering the Daughter's Nakedness: A Formal Analysis of Israelite Kinship Terminology and the Internal Logic of Leviticus 18 (The Library of Hebrew Bible. Old Testament Studies 476; London: Bloomsbury 2007).

Miller, G.D., Marriage in the Book of Tobit (Deuterocanonical and Cognate Literature Studies 10; Berlin - New York: de Gruyter 2011).

Montanari, F., The Brill Dictionary of Ancient Greek (Leiden - Boston, MA: Brill 2015).

Moore, C.A., Daniel, Esther and Jeremiah. The Additions (Anchor Bible 44; Garden City, NY: Doubleday 1977).

Moore, C.A., Tobit (Anchor Bible 40A; New York: Doubleday 1996).

Parchem, M., Księga Daniela (Nowy Komentarz Biblijny. Stary Testament 26; Częstochowa: Edycja Świętego Pawła 2008).

Pikuła, P., " "Nad córką zuchwałą wzmocnij czuwanie» (Syr 41,11). Syracydes jako moralista," Biblia, autorytet, moralność (ed. R. Pindel - S. Jędrzejewski) (Hermeneutica et Judaica 3; Kraków: Uniwersytet Papieski Jana Pawła II 2010) 59-73.

Pomeroy, S.B., Families in Classical and Hellenistic Greece (Oxford: Clarendon 1997).

Pomeroy, S.B., Goddesses, Whores, Wives, and Slaves: Women in Classical Antiquity (New York: Schocken 1975).

Pomeroy, S.B., Women in Hellenistic Egypt: From Alexander to Cleopatra (New York: Schocken 1984).

Robinson, B.P., “The Story of Jephthah and his Daughter: Then and Now," Biblica 85/3 (2004) 331-348.

Schüngel-Straumann, H., Tobit (Herders theologischer Kommentar. Altes Testament; Freiburg im Breisgau: Herder 2000).

Seifert, E., Tochter und Vater im Alten Testament. Eine ideologiekritische Untersuchung zur Verfügungsgewalt von Vätern über ihre Töchter (Neukirchen-Vluyn: Neukirchener 1997).

Skehan, P.W. - Di Lella, A.A., The Wisdom of Ben Sira (Anchor Bible 39; New York: Doubleday 1987).

Slater, P., The Glory of Hera. Greek Mythology and the Greek Family (Boston, MA: Beacon 1968).

Stiebert, J., Fathers and Daughters in the Hebrew Bible (Oxford: Oxford University Press 2013).

Westbrook, A.D., 'And He Will Take Your Daughters', Woman Story and the Ethical Evaluation of Monarchy in the David Narrative (The Library of Hebrew Bible/Old Testament Studies 610; London: Bloomsbury T\&T Clark 2016).

Wojciechowski, M., Apokryfy z Biblii greckiej (Rozprawy i Studia Biblijne 8; Warszawa: Vocatio 2001).

Wojciechowski, M., Księga Barucha (Nowy Komentarz Biblijny. Stary Testament 24/2; Częstochowa: Edycja Świętego Pawła 2016).

Wojciechowski, M., Księga Tobiasza czyli Tobita (Nowy Komentarz Biblijny. Stary Testament 12; Częstochowa: Edycja Świętego Pawła 2005).

Xeravits, G.G., "Take courage, o Jerusalem". Studies in the Psalms of Baruch 4-5 (Deuterocanonical and Cognate Literature Studies 25; Berlin: de Gruyter 2015).

Ziegler, J. (ed.), Sapientia Iesu Filii Sirach (Septuaginta Vetus Testamentum Graecum 12/2. Göttingen: Vandenhoeck \& Ruprecht 1965). 